\title{
2D and 3D cell cultures - a comparison of different types of cancer cell cultures
}

Marta Kapałczyńska ${ }^{1}$, Tomasz Kolenda ${ }^{1,2}$, Weronika Przybyła ${ }^{1}$, Maria Zajączkowska ${ }^{1}$, Anna Teresiak ${ }^{1}$, Violetta Filas ${ }^{3}$, Matthew Ibbs $^{3}$, Renata Bliźniak ${ }^{1}$, Łukasz Łuczewski' ${ }^{4}$, Katarzyna Lamperska ${ }^{1}$

\begin{abstract}
${ }^{1}$ Laboratory of Cancer Genetics, Greater Poland Cancer Centre, Poznan, Poland ${ }^{2}$ Postgraduate School of Molecular Medicine, University of Warsaw, Warsaw, Poland ${ }^{3}$ Department of Tumour Pathology, Greater Poland Cancer Centre, Poznan, Poland ${ }^{4}$ Department of Head and Neck Surgery, Greater Poland Cancer Centre, Poznan University of Medical Sciences, Poznan, Poland
\end{abstract}

Submitted: 9 February 2016

Accepted: 27 June 2016

Arch Med Sci 2018; 14, 4: 910-919

DOI: https://doi.org/10.5114/aoms.2016.63743

Copyright @ 2016 Termedia \& Banach

\begin{abstract}
Cell culture is a widely used in vitro tool for improving our understanding of cell biology, tissue morphology, and mechanisms of diseases, drug action, protein production and the development of tissue engineering. Most research regarding cancer biology is based on experiments using two-dimensional (2D) cell cultures in vitro. However, 2D cultures have many limitations, such as the disturbance of interactions between the cellular and extracellular environments, changes in cell morphology, polarity, and method of division. These disadvantages led to the creation of models which are more closely able to mimic conditions in vivo. One such method is three-dimensional culture (3D). Optimisation of the culture conditions may allow for a better understanding of cancer biology and facilitate the study of biomarkers and targeting therapies. In this review, we compare 2D and 3D cultures in vitro as well as different versions of 3D cultures.
\end{abstract}

Key words: co-culture, cell culture methods, 3D culture, 2D culture, cancer research.

\section{Cell cultures as a research model}

Studies on the mechanisms underlying the formation, function and pathology of tissues and organs are manageable largely due to the use of cell culture systems and animal models [1].

Harrison carried out the first cell cultures in 1907 during research into the origin of nerve fibres [2]. Since then, the method has been improved and used to observe the growth and differentiation of cells outside the body $[3,4]$. Nowadays, experiments can be conducted using primary cells isolated directly from the donors' material or using established cultures deposited in cell banks [5]. Primary cultures are isolated from living organisms and usually contain populations of different cell types present in the source tissue. In this case, it is important to isolate the correct cell type [5]. Characteristic features of primary cell lines are: i) difficulties with isolation and ii) short life span. On the other hand, they closely mimic the in vivo genetic features of tumours and thus make it possible to perform some functional experiments. An alternative option is the use of an established cell line. Bioresource centres, such as

\author{
Corresponding author: \\ Tomasz Kolenda, \\ Katarzyna Lamperska \\ Laboratory \\ of Cancer Genetics \\ Greater Poland \\ Cancer Centre \\ 15 Garbary St \\ 61-866 Poznan, Poland \\ Phone: +486188506 68 \\ E-mail: kolenda.tomek@ \\ gmail.com, kasialam@o2.pl
}


the ATCC (American Type Culture Collection), offer characterized models of various types of cancer cell lines that are routinely used in research [6].

Cell cultures make it possible to understand cell biology, tissue morphology, mechanisms of diseases, drug action, protein production and the development of tissue engineering [7]. They are often used in the preclinical research of many drugs, in cancer research, and in studies on gene function [5].

The choice of the most appropriate cell culture methods in the area of cancer research may allow us to better understand tumour biology, and hence to optimize radio- and chemotherapy, or even to find new treatment strategies [8].

The cultures can be carried out under adherent conditions wherein the cells are attached to a glass or plastic dish or in a suspension, which in some cases (e.g. cultures of lymphocytes) corresponds more faithfully to the natural environment [6]. The most commonly used type of cell culture is the $2 \mathrm{D}$ model, but recently the $3 \mathrm{D}$ culture method has been gaining in popularity (Figure 1) [9]. Depending on the type of culture chosen, cell behaviour differs in many aspects [7].

\section{D cultures}

In adherent 2D cultures, cells grow as a monolayer in a culture flask or in a flat petri dish, attached to a plastic surface [10].

The advantages of 2D cultures are associated with simple and low-cost maintenance of the cell culture and with the performance of functional tests. Unfortunately, adherent cultures also have

A

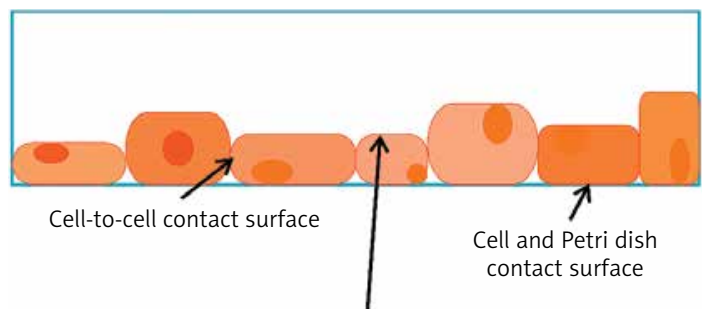

Cell and medium contact surface

C

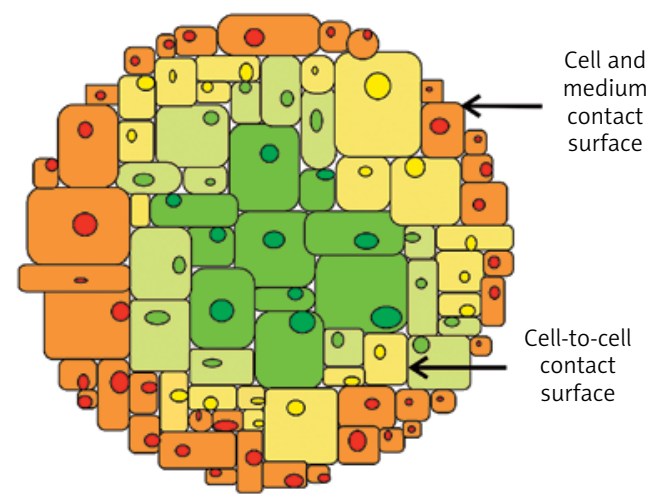

numerous disadvantages. First, 2D cultured cells do not mimic the natural structures of tissues or tumours (Figure 2 A). In this culture method, cellcell and cell-extracellular environment interactions are not represented as they would be in the tumour mass. These interactions are responsible for cell differentiation, proliferation, vitality, expression of genes and proteins, responsiveness to stimuli, drug metabolism and other cellular functions $[9,11-13]$. After isolation from the tissue and transfer to the 2D conditions, the morphology of the cells is altered, as is the mode of cell division. The loss of diverse phenotype is also a result of $2 \mathrm{D}$ culturing $[14,15]$. The changed morphology of the cells can affect their function [16, 17], the organization of the structures inside the cell, secretion and cell signalling $[18,19]$. Due to disturbances in interactions with the external environment, cells growing adherently lose their polarity [20], which changes the response of those cells to various phenomena, such as to apoptosis [21, 22]. Another drawback of $2 \mathrm{D}$ culture is that the cells in the monolayer have unlimited access to the ingredients of the medium such as oxygen, nutrients, metabolites and signal molecules. For cancer cells in vivo, the availability of nutrients, oxygen, and so forth, is more variable because of the natural architecture of the tumour mass [9]. Furthermore, it has been observed that the 2D system changes the gene expression and splicing, topology and biochemistry of the cell [23-26]. In addition, adherent cultures are usually monocultures and allow for the study of only one cell type [27], which results in a lack of tumour

B

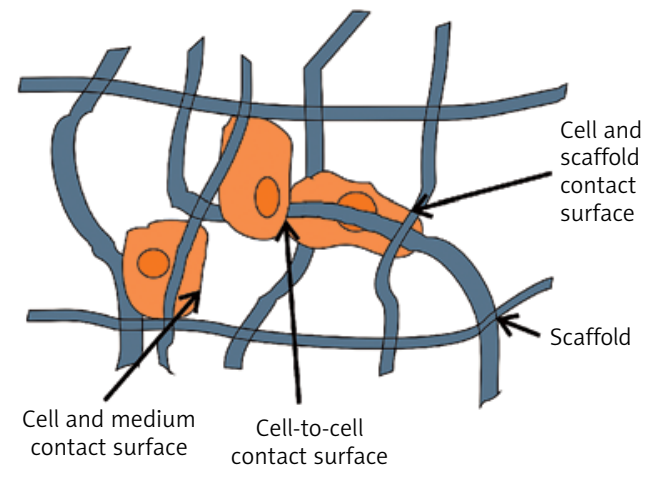

Figure 1. Types of cell culture methods commonly used in research studies. A - Cells flattened in a monolayer on the bottom of the culture vessel. They are in contact with the culture vessel, neighbouring cells, and the culture medium. B - Cells attached to a scaffold are in contact with the scaffolding, neighbouring cells, and the culture medium. C - A group of cells suspended in the culture medium or cultivated in gel-like substance; the cells are in contact with neighbouring cells and with the culture medium 

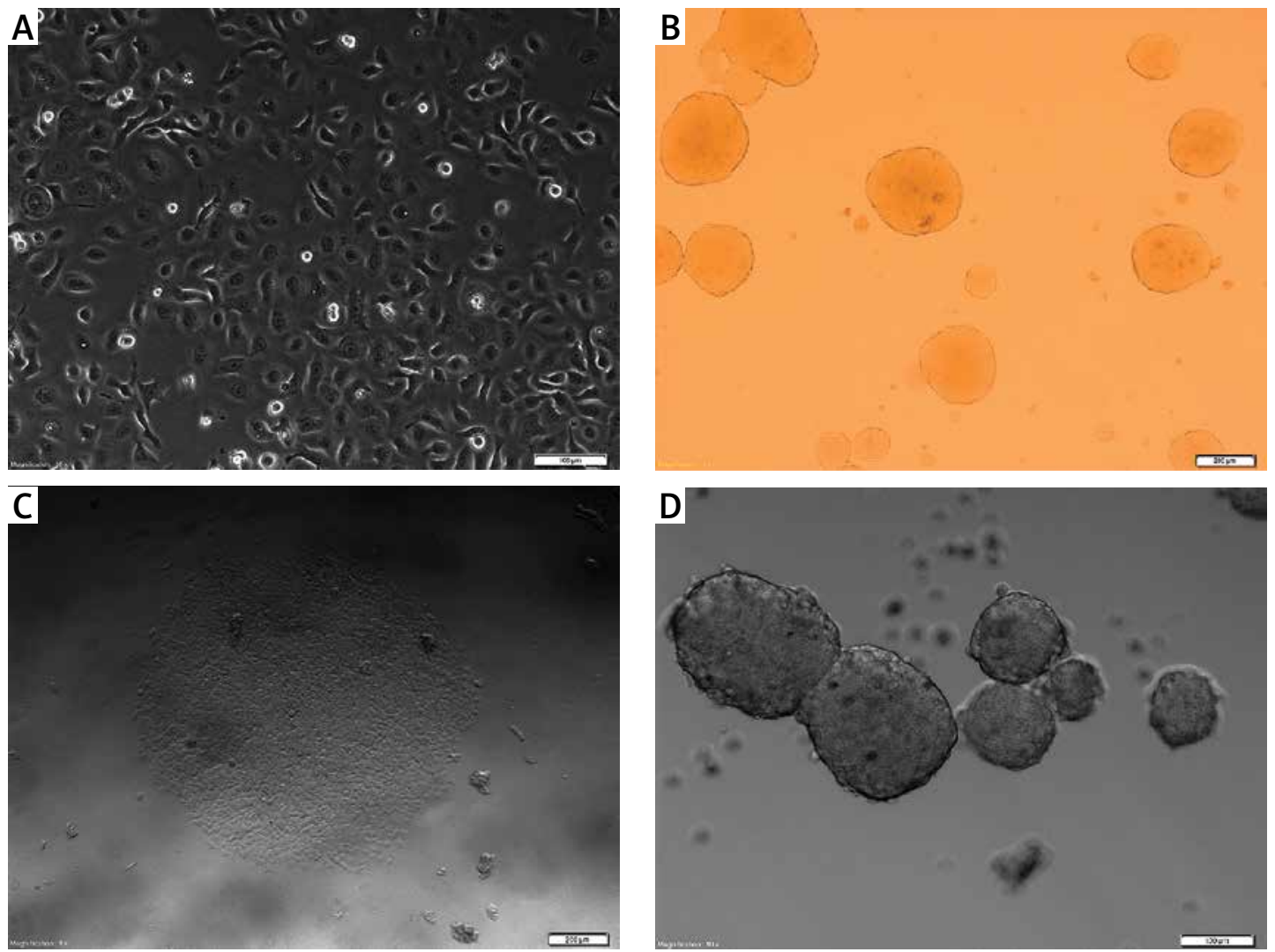

$E$
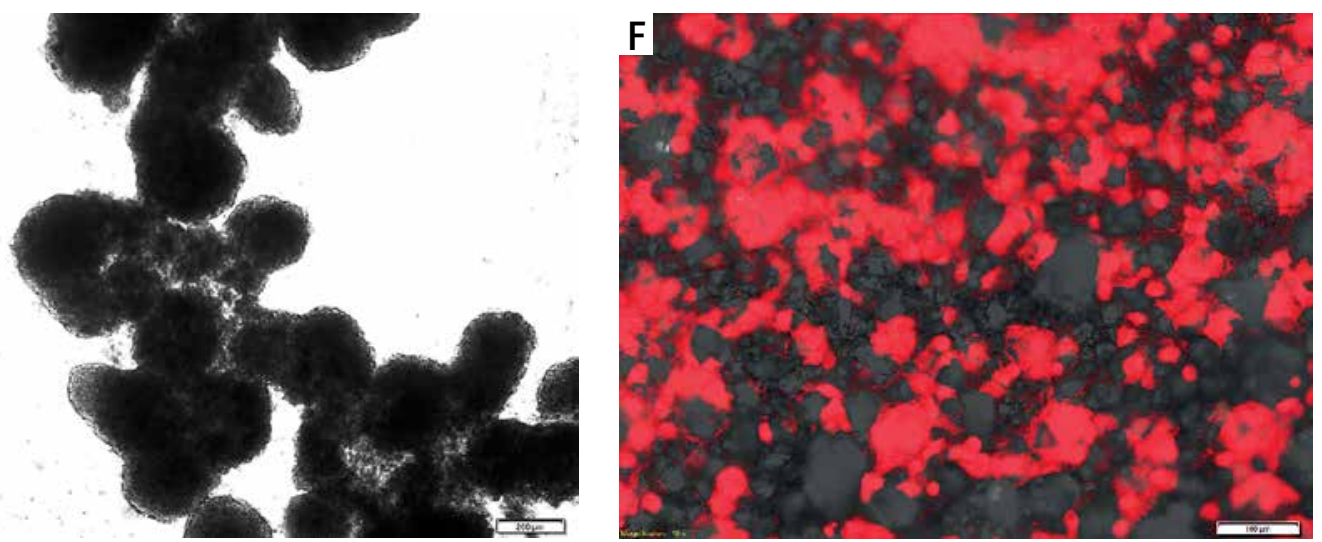

Figure 2. FaDu cell line cultured under various conditions. The FaDu cells were maintained in adherent conditions with standard medium (10\% FBS) and next detached and placed as single cells in different (A-F) culture conditions in standard medium. A - flattened cells growing as a monolayer under 2D conditions (scale bar represents $100 \mu \mathrm{m}$ ); B - 3D structures in soft agar, single cells suspended in a gel are visible (scale bar represents $200 \mu \mathrm{m}$ ); C - adherent colonies formed between layers of soft agar (scale bar represents $200 \mu \mathrm{m}$ ); D - 3D structure formed on non-adherent plate (scale bar represents $100 \mu \mathrm{m}$ ); E - tissue-like structures formed by attached single spheres cultivated on ultra-low attachment plates (scale bar represents $200 \mu \mathrm{m}$ ); F - cells (red) cultured using 3D scaffold system with visible membrane pores (scale bar represents $100 \mu \mathrm{m}$ )

microenvironment, or niches, which in vivo are required by cancer-initiating cells [28, 29].

Owing to the many disadvantages of $2 \mathrm{D}$ systems, there was a need to find alternative models, better able to mimic a natural tumour mass, such as 3D culture systems (Table I).

\section{D cultures}

One of the first three-dimensional cultures was made in soft agar solution, and was carried out by Hamburg and Salmon in the 1970s [30]. Since then, striking similarities between the morphology and behaviour of cells growing in a tumour mass and in cells cultured under 3D conditions have been well described and documented $[9,31]$

Due to the method of preparation, 3D models can be divided into: i) suspension cultures on non-adherent plates (Figure $2 \mathrm{C}$ ); ii) cultures in concentrated medium or in gel-like substances (Fig- 
Table I. Comparison of 2D and 3D cell culture methods

\begin{tabular}{|c|c|c|c|}
\hline Type of culture & 2D & 3D & Ref. \\
\hline $\begin{array}{l}\text { Time of culture } \\
\text { formation }\end{array}$ & Within minutes to a few hours & From a few hours to a few days & {$[11,34,57]$} \\
\hline Culture quality & $\begin{array}{l}\text { High performance, reproducibility, } \\
\text { long-term culture, easy to interpret, } \\
\text { simplicity of culture }\end{array}$ & $\begin{array}{c}\text { Worse performance and reproducibility, } \\
\text { difficult to interpret, cultures more } \\
\text { difficult to carry out }\end{array}$ & {$[12]$} \\
\hline In vivo imitation & $\begin{array}{l}\text { Do not mimic the natural structure } \\
\text { of the tissue or tumour mass }\end{array}$ & $\begin{array}{c}\text { In vivo tissues and organs are in 3D } \\
\text { form }\end{array}$ & [35] \\
\hline $\begin{array}{l}\text { Cells } \\
\text { interactions }\end{array}$ & $\begin{array}{c}\text { Deprived of cell-cell and cell- } \\
\text { extracellular environment interactions, } \\
\text { no in vivo-like microenvironment and } \\
\text { no "niches" }\end{array}$ & $\begin{array}{l}\text { Proper interactions of cell-cell and } \\
\text { cell-extracellular environment, } \\
\text { environmental "niches" are created }\end{array}$ & $\begin{array}{c}{[13,28,29,} \\
36,37]\end{array}$ \\
\hline $\begin{array}{l}\text { Characteristics } \\
\text { of cells }\end{array}$ & $\begin{array}{c}\text { Changed morphology and way of } \\
\text { divisions; loss of diverse phenotype } \\
\text { and polarity }\end{array}$ & $\begin{array}{l}\text { Preserved morphology and way of } \\
\text { divisions, diverse phenotype and } \\
\text { polarity }\end{array}$ & $\begin{array}{c}{[1,14-17} \\
20,38]\end{array}$ \\
\hline $\begin{array}{l}\text { Access to } \\
\text { essential } \\
\text { compounds }\end{array}$ & $\begin{array}{l}\text { Unlimited access to oxygen, nutrients, } \\
\text { metabolites and signalling molecules } \\
\text { (in contrast to in vivo) }\end{array}$ & $\begin{array}{c}\text { Variable access to oxygen, nutrients, } \\
\text { metabolites and signalling molecules } \\
\text { (same as in vivo) }\end{array}$ & {$[10,46]$} \\
\hline $\begin{array}{l}\text { Molecular } \\
\text { mechanisms }\end{array}$ & $\begin{array}{c}\text { Changes in gene expression, mRNA } \\
\text { splicing, topology and biochemistry } \\
\text { of cells }\end{array}$ & $\begin{array}{l}\text { Expression of genes, splicing, topology } \\
\text { and biochemistry of cells as in vivo }\end{array}$ & $\begin{array}{l}{[23-26} \\
42-45]\end{array}$ \\
\hline $\begin{array}{l}\text { Cost of } \\
\text { maintaining } \\
\text { a culture }\end{array}$ & $\begin{array}{l}\text { Cheap, commercially available tests and } \\
\text { the media }\end{array}$ & $\begin{array}{l}\text { More expensive, more time-consuming, } \\
\text { fewer commercially available tests }\end{array}$ & $\begin{array}{c}{[8,48,58} \\
75]\end{array}$ \\
\hline
\end{tabular}

ure $2 \mathrm{~B}$ ) and iii) cultures on a scaffold (Figure $2 \mathrm{E}$ ). All of these models are characterized in Table II.

The concept of 3D spheres is based on the creation of spheroid structures in which cells form various layers. This structure mimics the physical and biochemical features of a solid tumour mass. Morphological analysis of 40 tumour cell lines (originating from: glioblastoma, astrocytoma, Wilms' tumour, neuroblastoma, head and neck squamous cell carcinoma, melanoma, lung, breast, colon, prostate, ovarian, hepatocellular and pancreatic cancers) cultured in 3D spheroid conditions led to the identification of three distinct groups according to the architecture of spheroid shapes: i) tight spheroids, ii) compact aggregates and iii) loose aggregates [32, 33]. Some cells under non-adhesive conditions display reduced cell-cell and cell-matrix interactions, lose their anchorage, escape from anoikis, divide and create spheres [34].

Cells from the donor's tissues are cultured in multicellular, three-dimensional structures, imitating the architecture of the parental tissue more accurately than is possible in 2D models (Figure 3 ) [35]. This feature of 3D models is the result of the proper cell-cell and cell-environment interactions, created in order to obtain imitation of tissue structure. Cells can receive stimuli from the local environment, as happens in vivo $[36,37]$. Moreover, in $3 \mathrm{D}$ cultures, the morphology and polarity of the cells are maintained, and they can be restored to cells previously cultivated in 2D [1, 15, 38]. Furthermore, in some 3D systems, e.g. acinar-like spheroids, specific internal architecture with lumen formation is observed. This is the result of cell apoptosis in the central part of the spheroids. Cell proliferation depends on cell location and is higher in the peripheral part of the 3D structures [39-41]. Another important attribute of 3D culture is its similarity to cells growing in vivo in terms of cellular topology, gene expression, signalling and metabolism [42-47].

All these features create a specific platform which can be used for the study of the biology of cancer-initiating cells, invasion and metastatic processes, as well as for drug testing or for testing the response of cells to irradiation.

3D suspension culture systems are widely used as a model in studies, e.g. for increasing the population of cancer-initiating cells. This method allows for simple and low cost biological research $[37,48]$. The spheroids obtained from oral cancer cell lines show an increased proportion of cancer-initiating cells, probably due to the epithelial-mesenchymal transition process occurring under 3D conditions. The spheres exhibit loss of E-cadherin expression, and overexpression of fibronectin, Sox2, Oct4 and Nanog. Expression of putative stem cell markers such as CD133 and ALDH also occurs. Sphere-related enrichment of the cancer-initiating cell population is also why a lower number of cells, derived from the spheres, is needed to generate a tumour in xenograft mice, compared to parental cells [37]. It has been observed that the number of spheres is reduced with 
Table II. Characteristics of different 3D cell culture methods

\begin{tabular}{|c|c|c|c|c|}
\hline $\begin{array}{l}\text { Type of 3D } \\
\text { system }\end{array}$ & Description of cell culture & Advantages & Disadvantages & Ref. \\
\hline $\begin{array}{l}\text { Suspension } \\
\text { cultures on non- } \\
\text { adherent plates }\end{array}$ & $\begin{array}{l}\text { - Single cells are seeded } \\
\text { on non-adherent plates } \\
\text { with medium } \\
\text { - 3D structures can be } \\
\text { observed after } 3 \text { days of } \\
\text { culture }\end{array}$ & $\begin{array}{l}\text { - Simplicity, easiness and } \\
\text { speed of conducting } \\
\text { culture } \\
\text { - Bacterial plates or } \\
\text { non-adherent culture } \\
\text { plates can be used but } \\
\text { only for some cell lines } \\
\text { - Cells can be easily ex- } \\
\text { tracted from the medium } \\
\text { and used for further } \\
\text { experiments }\end{array}$ & $\begin{array}{l}\text { - Some cell lines need } \\
\text { expensive plates coated } \\
\text { with specific materials, } \\
\text { for example polystyrene } \\
\text { or covalently bound } \\
\text { hydrogel, because of } \\
\text { strong adhesion abilities } \\
\text { of cells } \\
\text { - Formation of aggre- } \\
\text { gates of cells as a result } \\
\text { of cells' movement in } \\
\text { medium }\end{array}$ & $\begin{array}{l}{[8,48,} \\
58,59]\end{array}$ \\
\hline $\begin{array}{l}\text { Cultures in } \\
\text { concentrated } \\
\text { medium or in } \\
\text { gel-like } \\
\text { substances }\end{array}$ & $\begin{array}{l}\text { - Single cells grow in } \\
\text { medium containing } \\
\text { substances with gelling } \\
\text { properties: i) dissolved } \\
\text { low-melting agarose with } \\
\text { cell medium is poured } \\
\text { on plate and incubated } \\
\text { until solidifying to obtain } \\
\text { the first, lower layer; } \\
\text { the top layer consist- } \\
\text { ing of agarose and the } \\
\text { medium with single cells } \\
\text { is added; ii) the cells are } \\
\text { flooded in Matrigel (mul- } \\
\text { tiprotein hydrogel) } \\
\text { - 3D structures can be } \\
\text { observed after } 7 \text { days of } \\
\text { culture }\end{array}$ & $\begin{array}{l}\text { - Soft agar allows to study } \\
\text { both the growth of } \\
\text { a single cell regardless } \\
\text { of attachment and the } \\
\text { phenomenon of escape } \\
\text { from anoikis } \\
\text { - Cells cultured in Matrigel } \\
\text { can be easily recovered } \\
\text { for further analysis } \\
\text { - Cells in Matrigel have } \\
\text { three-dimensional in- } \\
\text { teractions with the local } \\
\text { environment and form } \\
\text { tissue-like structures } \\
\text { - Used to study the ag- } \\
\text { gressiveness of the cells } \\
\text { and their potential for } \\
\text { metastasis }\end{array}$ & $\begin{array}{l}\text { - Difficulty in obtaining } \\
\text { spheres for certain } \\
\text { lines, inconvenient and } \\
\text { time-consuming prepara- } \\
\text { tion of the two layers of } \\
\text { agar and requirement of } \\
\text { long-term cultures } \\
\text { - Low repeatability of the } \\
\text { results } \\
\text { - The difficulty of extract- } \\
\text { ing cells from the agar } \\
\text { and immunofluorescence } \\
\text { staining of spheres, } \\
\text { - Materials constituting } \\
\text { the Matrigel contain } \\
\text { endogenous bioactive in- } \\
\text { gredients that influence } \\
\text { the structure formation }\end{array}$ & $\begin{array}{l}{[7,48} \\
58,59 \\
75-81]\end{array}$ \\
\hline $\begin{array}{l}\text { Cultures on } \\
\text { scaffold }\end{array}$ & $\begin{array}{l}\text { - The cells can migrate } \\
\text { among fibres and attach } \\
\text { to the scaffold, made of } \\
\text { biodegradable material } \\
\text { such as silk, collagen, } \\
\text { laminin, alginate, and fill } \\
\text { the space among fibres, } \\
\text { grow and divide }\end{array}$ & $\begin{array}{l}\text { - System is compatible } \\
\text { with commercially avail- } \\
\text { able functional tests, as } \\
\text { well as with DNA/RNA } \\
\text { and protein isolation kits } \\
\text { - Easy to prepare for } \\
\text { immunohistochemical } \\
\text { analysis }\end{array}$ & $\begin{array}{l}\text { - Cells attached to the } \\
\text { scaffolds flatten and } \\
\text { spread like the cells } \\
\text { cultured under adherent } \\
\text { conditions } \\
\text { - Scale of scaffolds and to- } \\
\text { pography of cell distribu- } \\
\text { tion may cause various } \\
\text { behaviour of the cell } \\
\text { - Materials used to } \\
\text { construct the scaffold } \\
\text { may affect the adhe- } \\
\text { sion, growth and cell } \\
\text { behaviour } \\
\text { - Cell observation and } \\
\text { cell extraction for some } \\
\text { analyses are restricted }\end{array}$ & $\begin{array}{c}{[7,8,37,} \\
82-90]\end{array}$ \\
\hline
\end{tabular}

the passage of time, and that the percentage of $\mathrm{ALDH}+/ \mathrm{CD} 44+$ cells decreases during the culture period, which may indicate an ongoing differentiation process [48]. Campos et al. observed that $\mathrm{ALDH}+/ \mathrm{CD} 44+$ cells create more orospheres, have higher proliferation rates and are more resistant to anoikis than ALDH-/CD44- cells growing in suspension conditions. This is probably caused by secreted endothelial factors which activate PI3k-Akt signalling, which in turn influences cells obtained from primary and metastatic cancers differently [49]. Sphere formation assays (in suspension or soft-agar cultures) are commonly used and inexpensive assays for evaluating the role of examined genes in self-renewal and maintenance of tumour stemness [50].

It is not surprising that tumour cells are less sensitive to drugs in $3 \mathrm{D}$ than in 2D cultures. This effect may be caused by reduced access to compounds in the medium or by pathophysiological differences due to hypoxia, or by changes in the cell cycle [35, 36]. Hsieh and colleagues showed that unstable culture conditions, which sometimes occur in vitro, and the type of culture meth- 
A

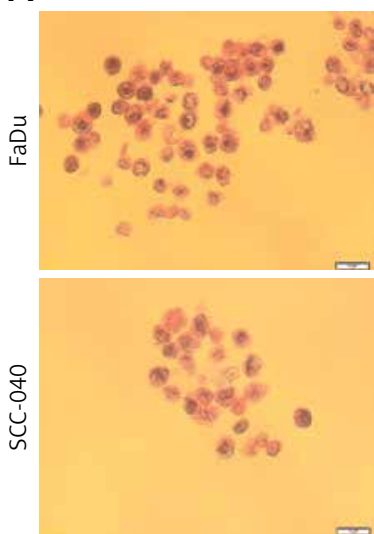

B

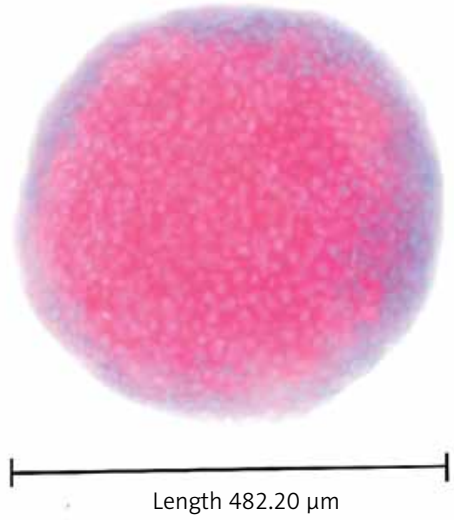

$3 \mathrm{D}$

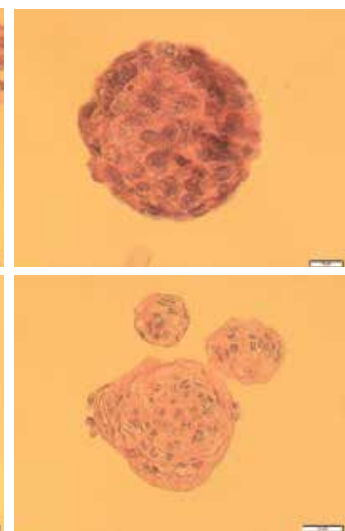

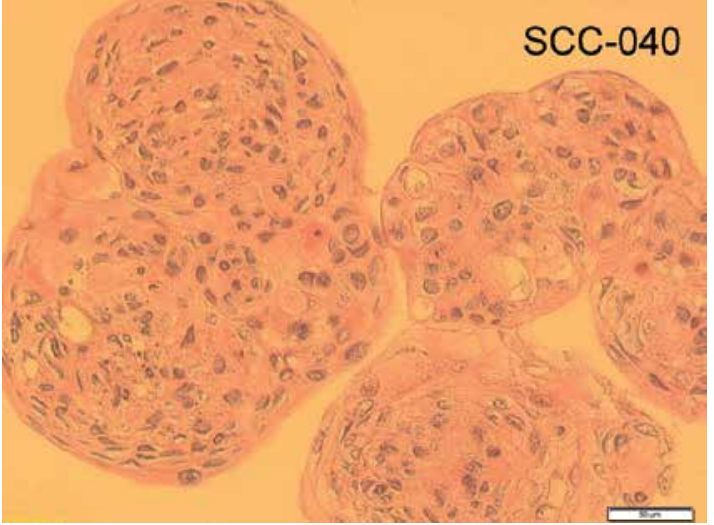

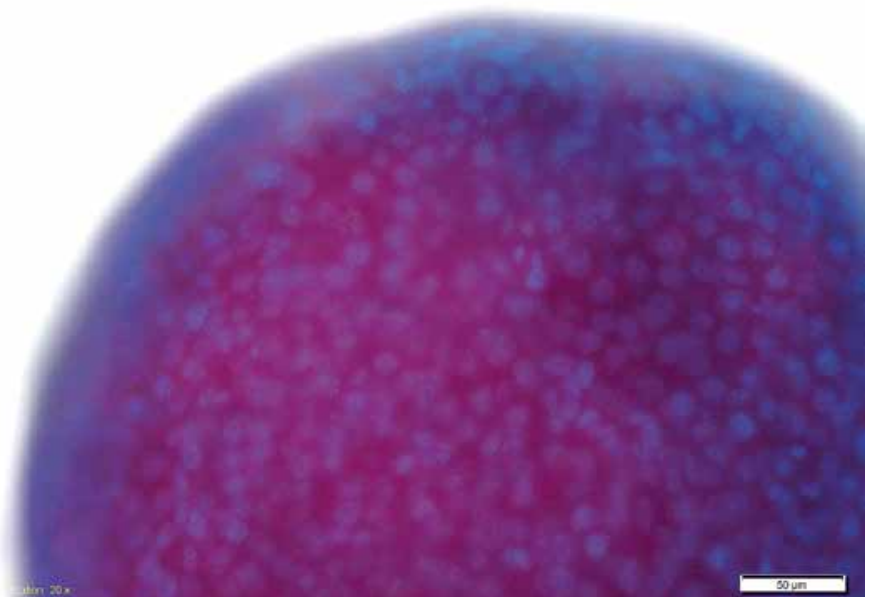

Figure 3. Structural architecture of 3D spheroids. The SCC-040 and FaDu cells were maintained in adherent condition with standard medium (10\% FBS) and next detached and placed as single cells on non-adherent plates in standard medium. The created spheroids were taken to make the formalin-fixed paraffin-embedded tissue sections (FFPET) and H\&E staining as well as DAPI staining. A - cross section through the cells growing in 2D and 3D cultures of SCC-040 and FaDu cell lines, H\&E staining (scale bars represent $20 \mu \mathrm{m}$ and $50 \mu \mathrm{m}$, respectively); B - 3D structure stained with DAPI; blue - nuclei, pink - cells (scale bar represents $50 \mu \mathrm{m}$ )

od used can significantly influence cellular metabolic activity, cell proliferation and, ultimately, changes in cell sensitivity to tested drugs. They also indicated that among 2D, 3D and spheroid models, only 3D cell culture, with the same cell density as natural tissue, shows a drug response comparable to that of a solid tumour [51].

Cell extracellular matrix (ECM) interactions seem to play an important role in the drug resistance of tumours. Cells growing in a 3D silk scaffold system, which have been found to be similar in fibre orientation and dimensions to native tumour ECM, are more resistant to paclitaxel. The use of artificial ECM is a good way to mimic the natural architecture of a tumour mass. It has been found that changes in ECM composition are associated with cancer progression and tumour features [52]. In this context, the use of 3D systems could avoid over- or underestimation of a specific drug in case of drug sensitivity and resistance, as well as its dosage $[35,36]$.
As mentioned above, the spheroids show different responses to drugs, but also the spatial structure of spheroids influences the irradiation response. Increased radiation survival is brought about by 3D architecture, which influences DNA heterochromatinization, characterized by deacetylation of histone $\mathrm{H} 3$ and high expression of heterochromatin protein $1 \alpha(\mathrm{HP} 1 \alpha)$. It should be noted that higher levels of heterochromatin partly protect DNA against radiation-dependent induction of double strand breaks in 3D structures. This phenomenon could be overcome by knockdown of histone deacetylase (HDAC) 1/2/4 or by application of the HDAC inhibitor LBH589. However, neither growth conditions nor HDAC modification affects ATM phosphorylation [53]. It has been shown that in some cases, such as head and neck cancers, integrins and their signalling cascades are critical for cell proliferation and survival. Use of the FAK/IGF-IR inhibitor TAE226 demonstrates strong radiosensitizing potential 
under in vitro 3D conditions, which strongly suggests that this inhibitor has potential in clinical practice [54]. Furthermore, the behaviour of cells cultured under 3D conditions shows that the combined targeting of FAK/IGF-IR by cetuximab and TAE226 induces cell death without the need for further irradiation [55].

Spheroids can be used to study the process of cell migration on ECM proteins, invasion into Matrigel, or simultaneously tissue invasion and angiogenesis. Characteristic features of migration are visible flattened cells surrounding spheroids (dispersed or radial migration). In the case of invasion the cells extend in visible invadopodia [35, 36]. Tissue invasion and angiogenesis assays can be performed by means of co-cultures of spheroids and embryoid bodies generated from mouse embryonic stem cells. This assay is designed to mimic xenograft tumour transplant systems [35, 36].

Moreover, 3D tissue culture system allows for the creation of imitation cancer tissue, with green fluorescent protein (GFP) expression and with the features of a solid tumour. The efficiency of transfection of anti-GFP oligonucleotides can be measured simply by fluorescence microscopy. Creation of systems with over- or down-regulated genes examined for usage in new treatment strategies is also possible. An example of application for 3D collagen matrix tissue structures could be in the establishment of an intracellular delivery system for oligonucleotides using the microneedle technique [56].

Apart from using 3D systems in the area of cancer research, they can also be applied in tissue engineering. For example, primary human salivary gland cells may be encapsulated in a 3D hyaluronic acid-based hydrogel scaffold, in order to obtain organized acinar-like spheroids with active protein secretion pathways. This approach might be used in the future to restore function to salivary glands damaged by radiation treatment [39-41].

A disadvantage of 3D cultures is that it requires the separation of single cells from spheroid structures by proteolytic degradation of single layers, which takes from several hours to a few days [57]. In many 3D methods, the efficiency, life-span, repeatability, and comfort of work are poorer than in the case of 2D systems [12]. It is often emphasized that a disadvantage of 3D structures is the fact that "spheres" can be formed, not from a single cell, but from a few cell clusters. However, even structures created as aggregates of several cells still have a three-dimensional form and seem to be a better model than flat, adherent cultures [58]. A tumour is not a homogeneous structure, but is built from tumour cells of various phenotypes. Furthermore, 2D cultures are, in fact, also a compound of various cell phenotypes. In spite of this, a homogeneous structure can be achieved from culture of a single cell, with only one genetic background in the concentrated culture medium, as is the case, for example, in soft agar or Matrigel [59].

The problem of low reproducibility in 3D culture was solved by Vinci et al., who described a three-dimensional spheroid-based functional assay for tumour target validation and drug evaluation. They used 96-well ultra-low attachment plates to create just one spheroid per well. The size of the obtained spheroids was reproducible and showed Gaussian distribution [32, 33].

Owing to the large number of problems associated with 2D systems, 3D models would appear to be a good alternative, that could be an intermediate model between 2D and animal studies $[1,30]$. The different technical approaches to obtaining 3D models possess their advantages and their limitations (Table II). The proper choice of 3D system mostly depends on the nature of the research. It must be emphasized that choosing the wrong model may influence the results. Clearly, the ideal 3D model does not exist. In some cases the use of a 2D culture system is enough, but 3D will be used more frequently in the future due to improvements to automation and cost reductions.

\section{D and 3D methods in co-culture systems}

A tumour is a mass composed of multiple cell types [60]. In co-cultures, different cell types are grown together in the same environment [61]. This type of culture was described in the 1970s as a system by which to examine communication among cells [62]. Such communication includes three types of intercellular interactions: cell-cell, cell-microenvironment and paracrine signalling by dissolved factors [61]. This allows us to observe interactions in functional structures that closely resemble interactions in vivo [63].

In co-culture we can distinguish between target cells and assistance cells that support their growth and development [61]. Studies show that both types of cells gain through co-culture [64].

Co-cultures can be divided into two types: direct and indirect [61]. In the first model, different types of cells are mixed and cultured together. In the second, cells are separated by a physical barrier [61]. Both types of co-culture can be carried out in 2D systems $[65,66]$, as well as in 3D models $[67,68]$. In direct cultures, we can observe all three types of interactions described above, which would appear to be of great importance in the study of cellular behaviour $[69,70]$. In contrast to the direct system, in the indirect model, the cells are deprived of interactions between the types of cells by the presence of a physical barrier $[68,71]$.

Our experience has shown that cells of different phenotypes do not grow with each other, even in direct models. Figure 4 shows mesenchy- 

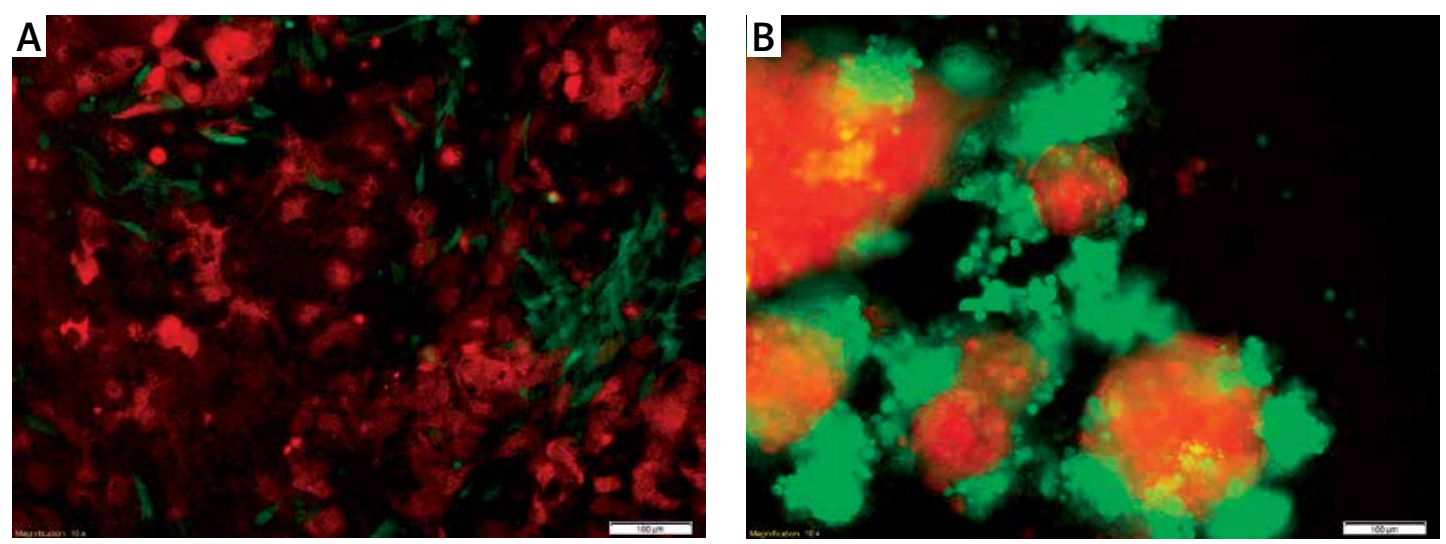

Figure 4. Co-culture of epithelial SCC-25 (red) and fibroblast MSU-1.1 (green) cell lines (scale bar represents 100 $\mu \mathrm{m})$. A - cells cultured under 2D conditions are flattened and attached to the plate surface. The epithelial SCC-25 cells (red) have typical rhombus-like shape and MSU-1.1 cells (green) are spindle-like and surround SCC-25 cells; B - SCC-25 (red) and MSU-1.1 (green) cells cultured under 3D conditions changed their own morphology due to the lack of attachment. Cells lose their typical shape and aggregate, creating more (SCC-25) and less (MSU-1.1) compact structures

mal fibroblast cells (green) cultured with epithelial cancer cells (red). It can be seen that the cells grow within the limits of their own line both in 2D and 3D systems. Moreover, it was observed that under 3D conditions, the SCC-25 line (red) formed a 3D structure, while the MSU-1.1 line (green) surrounded the established structures as assistance cells.

The downside of co-cultures is the inclusion, by necessity, of many variables (i.e. the degree of similarity and separation of the population, the components of the medium, volume and duration of culture), which must all be optimized so that all types of cultured cells might thrive. All these factors make co-cultures difficult to conduct [72].

\section{Conclusions}

Cell cultures are commonly used in genetic and biological cancer research $[6,48]$. They mimic in vivo conditions, to varying degrees, and may provide an alternative to animal models [73]. Currently, there are many forms of cell culture, which allows for the selection of a method well suited to the purpose of the study [74]. The most common research model is still the $2 \mathrm{D}$ culture system. However, owing to its limitations, 2D cultures are increasingly being seen as an inefficient model with which to study the processes associated with cellular responses to ionizing radiation or to exposure to chemotherapeutics. The 3D models are potentially a better approach in the search for new biomarkers and new treatment strategies, leading us closer to the goal of personalized medicine.

\section{Acknowledgments}

The experimental work to prepare figures was supported by Greater Poland Cancer Centre - grant no. $3 / 2015$ (95) and grant no. $17 / 2015$ (109); the preparation of the publication was supported by grant no. 13/2016 (128).

Marta Kapałczyńska and Tomasz Kolenda have contributed equally to this work.

\section{Conflict of interest}

The authors declare no conflict of interest.

\section{References}

1. Yamada K, Cukierman E. Modeling tissue morphogenesis and cancer in 3D. Cell 2007; 130: 601-10.

2. Harrison R. Observations of the living developing nerve fiber. Anat Rec 1907; 1: 116-28.

3. Harrison RG. The outgrowth of the nerve fiber as a mode of protoplasmic movement. J Exp Zool 1910; 9: 787-846.

4. Scudiero D, Shoemaker RH, Paull KD, et al. Evaluation of a soluble tetrazolium formazan assay for cell growth and drug sensitivity in culture using human and other tumor cell lines. Cancer Res 1988; 48: 4827-33.

5. Jacoby W, Pasten I. Methods in Enzymology: Cell Culture. Vol. 58. Academic Press, New York 1979.

6. Ryan J. Introduction to Animal Cell Culture. Technical Bulletin Corning 2003; 1-8.

7. Sanyal S. Culture and assay systems used for 3D cell culture. Corning 2014; 9: 1-18.

8. Aggarwal B, Danda D, Gupta S, Gehlot P. Models for prevention and treatment of cancer: problems vs promises. Biochem Pharmacol 2009; 78: 1083-94.

9. Pampaloni F, Reynaud EG, Stelzer EH. The third dimension bridges the gap between cell culture and live tissue. Nat Rev Mol Cell Biol 2007; 8: 839-45.

10. Breslin S, O'Driscoll L. Three-dimensional cell culture: the missing link in drug discovery. Drug Discov Today 2013; 18: 240-9.

11. Baker B, Chen C. Deconstructing the third dimension how 3D culture microenvironments alter cellular cues. J Cell Sci 2012; 125: 3015-24.

12. Hickman JA, Graeser R, de Hoogt R, et al. Three-dimensional models of cancer for pharmacology and cancer cell biology: capturing tumor complexity in vitro/ex vivo. Biotechnol J 2014; 9: 1115-28. 
13. Bissell MJ, Rizki A, Mian IS. Tissue architecture: the ultimate regulator of breast epithelial function. Curr Opin Cell Biol 2003; 15: 753-62.

14. von der Mark K, Gauss V, von der Mark H, Müller P. Relationship between cell shape and type of collagen synthesised as chondrocytes lose their cartilage phenotype in culture. Nature 1977; 267: 531-2.

15. Petersen OW, Rønnov-Jessen L, Howlett AR, Bissel MJ. Interaction with basement membrane serves to rapidly distinguish growth and differentiation pattern of normal and malignant human breast epithelial cells. Proc Natl Acad Sci USA 1992; 89: 9064-8.

16. Mahmud G, Campbell CJ, Bishop KJM, et al. Directing cell motions on micropatterned ratchets. Nat Phys 2009; 5 606-12.

17. Kilian K, Bugarija B, Lahn BT, et al. Geometric cues for directing the differentiation of mesenchymal stem cells. Proc Natl Acad Sci USA 2010; 107: 4872-7.

18. Debnath J, Brugge JS. Modelling glandular epithelia cancers in three-dimensional cultures. Nat Rev Cancer 2005; 5: 675-88.

19. Nelson CM, Bissell MJ. Of extracellular matrix, scaffolds, and signaling: tissue architecture regulates development, homeostasis, and cancer. Annu Rev Cell Dev Biol 2006; 22: 287-309.

20. Mseka T, Bamburg JR, Cramer LP. ADF/cofilin family proteins control formation of oriented actin-filament bundles in the cell body to trigger fibroblast polarization. J Cell Sci 2007; 120: 4332-44.

21. Weaver V, Lelièvre $S$, Lakins JN, et al. Beta4 integrin-dependent formation of polarized three-dimensional architecture confers resistance to apoptosis in normal and malignant mammary epithelium. Cancer Cell 2002; 2: 205-16.

22. Meyers J, Craig J, Odde DJ. Potential for control of signaling pathways via cell size and shape. Curr Biol 2003; 16: 1685-93.

23. Birgersdotter A, Sandberg R, Ernberg I. Gene expression perturbation in vitro - a growing case for three-dimensional (3D) culture systems. Semin Cancer Biol 2005; 15: 405-12.

24. Li C, Kato M, Shiue L, Shively JE, Ares M, Lin RJ. Cell type and culture condition-dependent alternative splicing in human breast cancer cells revealed by splicing-sensitive microarrays. Cancer Res 2006; 66: 1990-9.

25. Fuchs E, Tumbar T, Guasch G. Socializing with the neighbors: stem cells and their niche. Cell 2004; 116: 769-78.

26. Gomez-Lechon $M$, Jover R, Donato $T$, et al. Long-term expression of differentiated functions in hepatocytes cultured in three-dimensional collagen matrix. J Cell Physiol 1998; 77: 553-62.

27. Fischbach C, Chen R, Matsumoto T, et al. Egineering tumors with 3D scaffolds. Nat Methods 2007; 4: 855-60.

28. Gilbert PM, Havenstrite KL, Magnusson KE, et al. Substrate elasticity regulates skeletal muscle stem cell self-renewal in culture. Science 2010; 329: 1078-81.

29. Engler A, Sen S, Sweeney HL, Discher DE. Matrix elasticity directs stem cell lineage specification. Cell 2006; 126: 677-89.

30. Hamburger A, Salmon SE. Primary bioassay of human tumor stem cells. Science 1977; 197: 461-3.

31. Mazzoleni G, Di Lorenzo D, Steimberg N. Modelling tis sue in 3D: the next future of plarmaco-toxicology and food research? Genes Nutr 2009; 4: 13-22.

32. Vinci M, Gowan S, Boxall F, et al. Advances in establishment and analysis of three-dimensional tumor spheroid-based functional assays for target validation and drug evaluation. BMC Biol 2012; 10: 29.
33. Vinci M, Box C, Eccles SA. Three-dimensional (3D) tumor spheroid invasion assay. J Vis Exp 2015; 99: e52686.

34. Chen S, Chang Y, Nieh S, et al. Nonadhesive culture system as a model of rapid sphere formation with cancer stem cell properties. PLoS One 2012; 7: e31864.

35. Griffith LG, Swartz MA. Capturing complex 3D tissue physiology in vitro. Nat Rev Mol Cell Biol 2006; 7: 211-24.

36. Cawkill D, Eaglestone SS. Evolution of cell-based reagent provision. Drug Discov Today 2007; 12: 820-5.

37. Lee J, Cuddihy MJ, Kotov NA. Three-dimensional cell culture matrices: state of the art. Tissue Eng Part B Rev 2008; 14: 61-86.

38. Benya PD, Shaffer JD. Dedifferentiated chondrocytes reexpress the differentiated collagen phenotype when cultured in agarose gels. Cell 1982; 30: 215-24.

39. Pradhan-Bhatt S, Harrington DA, Duncan RL, et al. A novel in vivo model for evaluating functional restoration of a tissue-engineered salivary gland. Laryngoscope 2014; 124: 456-61.

40. Pradhan S, Liu C, Zhang C, Jia X, Farach-Carson MC, Witt RL. Lumen formation in three-dimensional cultures of salivary acinar cells. Otolaryngol Head Neck Surg 2010; 142: 191-5.

41. Pradhan-Bhatt S, Harrington DA, Duncan RL, Jia $X$, Witt RL, Farach-Carson MC. Implantable three-dimensional salivary spheroid assemblies demonstrate fluid and protein secretory responses to neurotransmitters. Tissue Eng Part A 2013; 19: 1610-20.

42. Ghosh S, Spagnoli GC, Martin I, et al. Three-dimensional culture of melanoma cells profoundly affects gene expression profile: a high density oligonucleotide array study. J Cell Physiol 2005; 204: 522-31.

43. Berthiaume F, Moghe PV, Toner M, Yarmush ML. Effect of extracellular matrix topology on cell structure, function, and physiological responsiveness: hepatocytes cultured in a sandwich configuration. FASEB J 1996; 10: 1471-84.

44. Semino CE, Merok JR, Crane GG, Panagiotakos G, Zhang S. Functional differentiation of hepatocyte-like spheroid structures from putative liver progenitor cells in three-dimensional peptide scaffolds. Differentiation 2003; 71: 262-70.

45. Powers MJ, Janigian DM, Wack KE, Baker CS, Beer Stolz D, Griffith LG. Functional behavior of primary rat liver cells in a three-dimensional perfused microarray bioreactor. Tissue Eng 2002; 8: 499-513.

46. Frieboes HB, Smith BR, Chuang Y, et al. An integrated computational/experimental model of tumor invasion. Cancer Res 2006; 66: 1597-604.

47. Marushima H, Shibata S, Asakura T, et al. Three-dimensional culture promotes reconstitution of the tumor-specific hypoxic microenvironment under TGF stimulation. Int J Oncol 2011; 39: 1327-36.

48. Krishnamurthy S, Nör JE. Orosphere assay: a method for propagation of head and neck cancer stem cells. Head Neck 2013; 35: 1015-21.

49. Campos MS, Neiva KG, Meyers KA, Krishnamurthy S, Nör JE. Endothelial derived factors inhibit anoikis of head and neck cancer stem cells. Oral Oncol 2012; 48: 26-32.

50. Lo WL, Yu CC, Chiou GY, et al. MicroRNA-200c attenuates tumour growth and metastasis of presumptive head and neck squamous cell carcinoma stem cells. J Pathol 2011; 223: 482-95.

51. Hsieh C, Chen Y, Huang S, Wang $H$, Wu M. The effect of primary cancer cell culture models on the results of drug chemosensitivity assays: the application of perfusion microbioreactor system as cell culture vessel. Biomed Res Int 2015; 2015: 470283. 
52. Bulysheva AA, Bowlin GL, Petrova SP, Yeudall WA. Enhanced chreemosistance of squamous carcinoma cells grown in 3D cryogenic electrospun scaffolds. Biomed Mater 2013; 8: 055009.

53. Storch K, Eke I, Borgmann K, et al. Three-dimensional cell growth confers radioresistance by chromatin density modification. Cancer Res 2010; 70: 3925-34.

54. Hehlgans S, Lange I, Eke I, Cordes N. 3D cell cultures of human head and neck squamous cell carcinoma cells are radiosensitized by the focal adhesion kinase inhibitor TAE226. Radiother Oncol 2009; 83: 371-8.

55. Eke I, Cordes N. Dual targeting of EGFR and focal adhesion kinase in 3D grown HNSCC cell cultures. Radiother Oncol 2011; 99: 279-86.

56. Luo Z, Ye T, Ma Y, Gill HS, Nitin N. Microprecision delivery of oligonucleotides in a 3D tissue model and its characterization using optical imaging. Mol Pharm 2013; 10: 2868-79.

57. Khetan S, Burdick JA. Patterning network structure to spatially control cellular remodeling and stem cell fate within 3-dimensional hydrogels. Biomaterials 2010; 31 8228-34.

58. Weiswald L, Bellet D, Dangles-Marie V. Spherical cancer models in tumor biology. Neoplasia 2015; 17: 1-15.

59. Li Q, Chen C, Kapadia A, et al. 3D models of epithelialmesenchymal transistion in breast cancer metastasis. Jiomol Screen 2011; 16: 141-54.

60. Heppner GH. Tumor heterogeneity. Cancer Res 1984; 44: 2259-65.

61. Paschos N, Brown WE, Eswaramoorthy R, Hu J, Athanasiou K. Advances in tissue engineering through stem cell-based co-cultures. J Tissue Eng Regen Med 2014; 9: 488-503.

62. Lawrance TS, Beers WH, Gilula NB. Transmission of hormonal stimulation by cell-to-cell communication. $\mathrm{Na}$ ture 1978; 272: 501-6.

63. Hendriks J, Riesle J, van Blitterswijk CA. Co-culture in cartilage tissue engineering. J Tissue Eng Regen Med 2007; 1: 170-8.

64. Bian L, Zhai DY, Mauck RL, Burdick JA. Coculture of human mesenchymal stem cells and articular chondrocytes reduces hypertrophy and enhances functional properties of engineered cartilage. Tissue Eng A 2011; 17: $1137-45$.

65. Guan X, Delo DM, Atala A, Soker S. In vitro cardiomyogenic potential of human amniotic fluid stem cells. J Tissue Eng Regen Med 2011; 5: 220-8.

66. Vats A, Bielby RC, Tolley N, et al. Chondrogenic differentiation of human embryonic stem cells: the effect of the micro-evironment. Tissue Eng 2006; 12: 1687-97.

67. Traphagen S, Titushkin I, Sun S, Wary KK, Cho M. Endothielial invasive response in a co-culture model with physically-induced osteodifferentiation. J Tissue Eng Regen Med 2013; 7: 621-30

68. Ou DB, He Y, Chen R, et al. Three-dimensional co-culture facilitates the differentiation of embryonic stem cells into mature cardiomyocytes. J Cell Biochem 2011; 112: 3555-62.

69. Kawada H, Ando K, Tsuji T, et al. Rapid ex vivo expansion of human umbilical cord hematopoietic progenitors using a novel culture system. Exp Hematol 1999; 27: 904-15.

70. Yamamoto Y, Mochida J, Sakai D, et al. Upregulation of the viability of nucleus pulposus cells by bone marrow-derived stromal cells: significance of direct cell-to-cell contact in coculture system. Spine 2004; 29: 1508-14.

71. Liu Y, Chan-Park MB. A biomimetic hydrogel based on methacrylated dextran-graft-lysine and gelatin for 3D smooth muscle cell culture. Biomaterials 2010; 31: 1158-70.

72. Goers L, Freemont P, Polizzi KM. Co-culture systems and technologies: taking synthetic biology to the next level. J R Soc Interface 2014; 11: 20140065.

73. Polson AG, Fuji RN. The successes and limitations of preclinical studies in predicting the pharmacodynamics and safety of cell-surface-targeted biological agents in patients. Br J Pharmacol 2012; 166: 1600-2.

74. Stasiak P, Sznitowska M. Zastosowanie hodowli komórkowych w badaniach biofarmaceutycznych. Farm Pol 2010; 66: 228-34.

75. Sodunke TR, Turner KK, Caldwell SA, McBride KW, Reginato MJ, Noh HM. Micropatterns of Matrigel for three-dimensional epithelial cultures. Biomaterials 2007; 28: 4006-16.

76. Friedrich J, Seidel C, Ebner R, Kunz-Schughart LA. Spheroid-based drug screen: considerations and practical approach. Nat Protoc 2009; 4: 309-24.

77. Kleinman HK, Martin GR. Matrigel: basement membrane matrix with biological activity. Semin Cancer Biol 2005; 15: 378-86.

78. Dawson E, Mapili G, Erickson K, Tagvi S, Roy K. Biomaterials for stem cell differentiation. Adv Drug Deliv Rev 2008; 60: 215-28

79. Kim JB. Three-dimensional tissue culture models in cancer biology. Semin Cancer Biol 2005; 15: 365-77.

80. Xu K, Buchsbaum RJ. Isolation of mammary epithelial cells from three-dimensional mixed-cell spheroid co-culture. J Vis Exp 2012; 62: pii: 3760.

81. Fridman R, Kibbey MC, Royce LS, et al. Enhanced tumor growth of both primary and established human and murine tumor cells in athymic mice after coinjection with matrigel. JNCI J Natl Cancer Inst 1991; 83: 769-74.

82. Jastrzebska K, Kucharczyk K, Florczak A, Dondajewska E, Mackiewicz A, Dams-Kozlowska H. Silk as an innovative biomaterial for cancer therapy. Rep Pract Oncol Radiother 2014; 20: 87-98.

83. Glicklis R, Shapiro L, Agbaria R, Merchuk JC, Cohen S. Hepatocyte behavior within three-dimensional porous alginate scaffolds. Biotechnol Bioeng 2000; 67: 344-53.

84. Tan W, Krishnaraj R, Desai TA. Evaluation of nanostructured composite collagen-chitosan matrices for tissue engineering. Tissue Eng 2001; 7: 203-10.

85. Sourla A, Doillon C, Koutsilieris M. Three-dimensional type I collagen gel system containing MG-63 osteoblasts-like cells as a model for studying local bone reaction caused by metastatic cancer cells. Anticancer Res 1996; 16: 2773-80.

86. Justice BA, Badr NA, Felder RA. 3D cell culture opens new dimension in cell-based assays. Drug Discov Today 2009; 14: 102-7.

87. Cheng N, Estes BT, Awad H, Guilak F. Chondrogenic differentiation of adipose-derived adult stem cells in agarose, alginate, and gelatin scaffolds. Biomaterials 2004; 25: 3211-22.

88. Stevens MM, George JH. Exploring and engineering the cell surface interface. Science 2005; 310: 1135-8.

89. Curtis A, Wilkinson C. New depths in cell behaviour: reactions of cells to nanotopography. Biochem Soc Symp 1999; 65: 15-26.

90. Haycock JW. 3D cell culture: a review of current approaches and techniques. Methods Mol Biol 2011; 695: $1-15$. 